\title{
Prevalence and Associated Factors of Insulin Resistance in Adults from Maracaibo City, Venezuela
}

\author{
Valmore Bermudez, ${ }^{1}$ Juan Salazar, ${ }^{1}$ María Sofía Martínez, ${ }^{1}$ Mervin Chávez-Castillo, \\ Luis Carlos Olivar, ${ }^{1}$ María José Calvo, ${ }^{1}$ Jim Palmar, ${ }^{1}$ Jordan Bautista, ${ }^{1}$ Eduardo Ramos, \\ Mayela Cabrera, ${ }^{1}$ Freddy Pachano, ${ }^{2}$ and Joselyn Rojas ${ }^{1}$ \\ ${ }^{1}$ Endocrine and Metabolic Diseases Research Center, School of Medicine, University of Zulia, Maracaibo 4004, Venezuela \\ ${ }^{2}$ Morphologic Sciences Department and Pediatric Surgery Department, School of Medicine, University of Zulia, \\ Maracaibo 4004, Venezuela \\ Correspondence should be addressed to Valmore Bermudez; valmore@gmail.com
}

Received 13 March 2016; Accepted 26 May 2016

Academic Editor: Gerardo E. Guillén Nieto

Copyright (C) 2016 Valmore Bermudez et al. This is an open access article distributed under the Creative Commons Attribution License, which permits unrestricted use, distribution, and reproduction in any medium, provided the original work is properly cited.

\begin{abstract}
Background and Aim. Insulin resistance (IR) is a prominent pathophysiologic component in a myriad of metabolic disorders, including obesity, prediabetes, and type 2 diabetes mellitus, which are common in our locality. The objective of this study was to determine the prevalence of IR and factors associated with this condition in an adult population from Maracaibo city, Venezuela. Methodology. A cross-sectional, descriptive study with multistaged randomized sampling was carried out in 2026 adults. IR was defined as HOMA2-IR $\geq 2$. A multiple logistic regression model was constructed in order to evaluate factors associated with IR. Results. The prevalence of IR was $46.5 \%(n=943)$, with $46.7 \%(n=450)$ in the general population, $46.4 \%(n=493)$ in females, and $47.90 \%(n=970)$ in males $(p=0.895)$. IR prevalence tended to increase with age and was significantly greater in subjects aged $\geq 30$ years $\left(\chi^{2}=16.726 ; p=2.33 \times 10^{-4}\right)$. Employment, alcohol consumption, obesity, high triacylglycerides, low HDL-C, and dysglycemia were associated with greater odds of IR, whereas a high level of physical activity appeared to be weak protective factor against IR. Conclusions. The prevalence of IR is elevated in our locality. The main determinants of this condition appear to be the presence of obesity, high triacylglycerides, low HDL-C, dysglycemia, and alcohol intake.
\end{abstract}

\section{Introduction}

The term insulin resistance (IR) was coined in 1936 to describe a metabolic disturbance characterized by decreased cellular responsiveness to insulin signaling in insulin-dependent tissues such as skeletal muscle, liver, and adipose tissue [1]. IR has now been established to play a key role in pancreatic $\beta$ cell dysfunction and type 2 diabetes mellitus (DM2) [2]. This disease represents one of the leading causes of mortality in the adult population worldwide [3], with alarming projections for the future, with an estimated prevalence of $33 \%$ in adults in the USA by 2050 [4]. Furthermore, IR is a fundamental pathophysiologic component of several other endocrinemetabolic disorders, such as hypertension, dyslipidemias, polycystic ovary syndrome, metabolic syndrome, and cardiovascular disease $[5,6]$.
In light of the great morbidity and mortality rates associated with these disorders, prominent scientific effort has been directed to the refinement of tools for the detection and assessment of IR. In this regard, HOMA2-IR [7] stands as one of the most broadly accepted models in research settings yet remains relatively underutilized in our local clinical scenario. In this context, previous analyses by our research group have estimated specific cutoffs for this variable in our population [8], laying the groundwork for their potential clinical and epidemiologic use.

IR is intimately linked with psychobiologic habits such as smoking, alcohol consumption, hypercaloric diets, and physical inactivity. In turn, these factors can be strongly conditioned by demographic, social, and economic aspects, which shape daily human living. Thus, the objective of this 
study was to determine the prevalence and determinants of IR in the adult population of Maracaibo city, Venezuela.

\section{Materials and Methods}

2.1. Sample Selection. This report is part of the Maracaibo City Metabolic Syndrome Prevalence Study, a cross-sectional study whose purpose is to identify MS and cardiovascular risk factors in the adult population of Maracaibo, the second largest city of Venezuela. The sample (1,986 individuals) was calculated based on estimations of the city's population by our National Institute of Statistics $(1,428,043$ inhabitants for the year 2007). A total of 244 subjects (12\%) were added for oversampling, in order to increase accuracy of the estimates obtained from smaller subgroups from the overall sample, amounting to a total of 2,230 individuals. Maracaibo city is divided into parishes, each of which was proportionally sampled with a multistaged cluster method: In the first stage, clusters were represented by sectors from each of the 18 parishes, selecting 4 from each parish by simple randomized sampling. In the second phase, clusters were represented by city blocks within each sector, which were selected by simple randomized sampling using a random number generation tool. Further details of the sampling process have been previously published elsewhere [9].

2.2. Ethical Considerations. All participants signed written consent prior to undergoing physical examination and blood sample collection. All procedures were approved by the Ethics Committee of the Endocrine and Metabolic Diseases Research Center of The University of Zulia, Maracaibo, Venezuela.

2.3. Subject Evaluation. Data were collected through completion of a full clinical record carried out by trained personnel, which encompassed interrogation regarding ethnic origin, marital status (single, married, cohabiting, or divorced), occupational status (employed or unemployed), and educational status, under the following definitions: (a) illiterate, subjects with no reading or writing skills; (b) primary education, those who attended or finished primary or middle school; (c) secondary education, those who attended or finished high school; and (d) high education, those who attended or finished college/university [9]. Socioeconomic status was assessed with the Graffar scale modified by Méndez-Castellano for the Venezuelan population [10]. This tool allows stratification of the population according to four variables: occupation of the head of household, educational level of the subject's parents, income source, and housing conditions. Each of these items is rated in a Likert-type scale from 1 to 5 ( 1 representing the best possible scenarios and 5 the worst). The scores for each item are tallied into a total integrated score ranging from 4 to 20 points, categorized as follows: Stratum I or High Class (4-6 points); Stratum II or Middle-High Class (7-9 points); Stratum III or Middle Class (10-12 points); Stratum IV or Relative Poverty (13-16 points), and Stratum V or Critical Poverty (17-20 points).
2.3.1. Smoking Habit. Based on information obtained during the clinical interview, subjects were categorized by their smoking habits as follows [11]: (a) nonsmokers, individuals who had never smoked or had smoked $<100$ cigarettes in their lifetime; (b) current smokers, subjects who had smoked $\geq 100$ cigarettes in their lifetime or reported current habitual smoking at the time of evaluation or had quit smoking less than one year prior to our assessment; and (c) past smokers, individuals who had consumed $\geq 100$ cigarettes in their lifetime and quit over one year prior to our questioning.

2.3.2. Alcohol Consumption. For the assessment of alcohol intake, subjects were asked to estimate the amount of alcoholic drinks they consumed within a month, with the approximate quantity and frequency of daily intake for each type of drink: beer, spirits, and wine and its derivatives. Accounting for the standard content of alcohol grams in each kind of beverage [12], daily intake of alcohol grams was calculated through the following formula [13]:

$$
\frac{\text { Daily consumed }(\mathrm{mL}) \times \text { degrees of alcohol } \times 0.8}{100},
$$

where 0.8 is a constant representing ethanol density in drinks. Based on this estimation, drinkers were defined as subjects who consumed $\geq 1$ gram of alcohol daily [14].

2.3.3. Physical Activity. Physical activity (PA) was assessed with the International Physical Activity Questionnaire (IPAQ) [15]. For statistical analysis, PA was evaluated in 4 domains: occupational, household, transport, and leisure. In each of these domains, subjects were categorized as follows: (a) inactive, MET/week $=0$, or (b) active, MET/week $>0$. The latter were then subcategorized by gender-specific MET/week quintiles in each domain (Table 1).

2.3.4. Blood Pressure. Blood pressure (BP) was taken with subjects sitting down with their feet on the floor following 15 minutes of rest, determined through the auscultatory method with a calibrated mercury sphygmomanometer, identifying Korotkoff's phases I and V as systolic and diastolic BP, respectively. BP was determined 3 times, with 15 minutes in between each take, on two different days; results were classified by the Eighth Joint National Committee on Prevention, Detection, Evaluation, and Treatment of High Blood Pressure (JNC-8) guidelines [16].

2.3.5. Anthropometry. An electrical bioelectric scale was used to obtain weight (Tanita, TBF-310 GS Body Composition Analyzer, Tokyo, Japan). Height was measured using a calibrated metric measurement tape, with the subject standing up barefoot. Body Mass Index (BMI) was calculated with the following formula: [weight/height ${ }^{2}$ ] expressing results as $\mathrm{kg} / \mathrm{m}^{2}$. According to their BMI, subjects were sorted in 3 categories: (a) BMI $\leq$ 24.9; (b) 25-29.9; and (c) $\geq 30$ [17]. Waist circumference (WC) was evaluated with calibrated measuring tapes in accordance with the anatomical landmarks proposed by the USA National Institutes of Health protocol [18]. 
TABLE 1: Gender-specific MET quintiles for each domain of physical activity (Maracaibo, Venezuela, 2015).

\begin{tabular}{|c|c|c|c|c|}
\hline \multirow{2}{*}{$\begin{array}{l}\text { MET quintiles* } \\
\text { Work } \\
\text { domain }\end{array}$} & \multicolumn{2}{|c|}{ Females } & \multicolumn{2}{|c|}{ Males } \\
\hline & Lower limit & Upper limit & Lower limit & Upper limit \\
\hline Very low & 33.00 & 385.99 & 33.00 & 714.99 \\
\hline Low & 386.00 & 1201.49 & 715.00 & 2042.09 \\
\hline Moderate & 1201.50 & 2751.59 & 2042.10 & 3578.39 \\
\hline High & 2751.60 & 4546.79 & 3578.40 & 6495.59 \\
\hline Very high & 4546.80 & & 4546.80 & \\
\hline $\begin{array}{l}\text { Transport } \\
\text { domain }\end{array}$ & Lower limit & Upper limit & Lower limit & Upper limit \\
\hline Very low & 33.00 & 131.99 & 33.00 & 164.99 \\
\hline Low & 132.00 & 230.99 & 165.00 & 257.49 \\
\hline Moderate & 231.50 & 346.49 & 247.50 & 521.09 \\
\hline High & 346.50 & 700.79 & 521.10 & 1385.99 \\
\hline Very high & 700.80 & & 1386.00 & \\
\hline $\begin{array}{l}\text { Household } \\
\text { domain }\end{array}$ & Lower limit & Upper limit & Lower limit & Upper limit \\
\hline Very low & 30.00 & 539.99 & 30.00 & 269.99 \\
\hline Low & 540.00 & 1139.99 & 270.00 & 629.99 \\
\hline Moderate & 1140.00 & 1919.99 & 630.00 & 1084.99 \\
\hline High & 1920.00 & 3779.99 & 1085.00 & 2429.99 \\
\hline Very high & 3780.00 & & 2430.00 & \\
\hline $\begin{array}{l}\text { Leisure } \\
\text { domain }\end{array}$ & Lower limit & Upper limit & Lower limit & Upper limit \\
\hline Very low & 33.00 & 230.99 & 33.00 & 296.99 \\
\hline Low & 321.00 & 445.49 & 297.00 & 791.99 \\
\hline Moderate & 445.50 & 742.49 & 792.00 & 1532.39 \\
\hline High & 742.50 & 1798.79 & 1532.40 & 2879.99 \\
\hline Very high & 1798.80 & & 2880.00 & \\
\hline
\end{tabular}

* Obtained from IPAQ scoring. Subjects with 0 MET were excluded from quintiles and classified separately as inactive.

2.3.6. Laboratory Analysis. Overnight fasting determination of glucose, total cholesterol, triacylglycerides (TAG), and HDL-C was done with an automated analyzer (Human Gesellschaft für Biochemica und Diagnostica mbH, Germany); the intra-assay variation coefficients for total cholesterol, TAG, and HDL-C were $3 \%, 5 \%$, and $5 \%$, respectively. LDL-C and VLDL-C levels were calculated applying Friedewald's formula [19] but when TAG levels were $<400 \mathrm{mg} / \mathrm{dL}$. LDL-C concentrations were directly measured through lipoprotein electrophoresis and densitometry with a BioRad GS-800 optical densitometer. Insulin was quantified using ultrasensitive ELISA double-sandwich methodology (DRG Instruments GmbH, Germany, Inc.).

2.3.7. Diagnosis of Metabolic Syndrome. The metabolic syndrome was defined by the criteria from the IDF/NHLBI/ AHA/WHF/IAS/IASO-2009 consensus [20], which require the presence of $\geq 3$ of the following components: (a) low HDL-C, $<50 \mathrm{mg} / \mathrm{dL}$ in females or $<40 \mathrm{mg} / \mathrm{dL}$ in males; (b) high TAG, $\geq 150 \mathrm{mg} / \mathrm{dL}$; (c) elevated WC, $\geq 80 \mathrm{~cm}$ in females or $\geq 90 \mathrm{~cm}$ in males; (d) hyperglycemia, fasting glycemia $\geq 100 \mathrm{mg} / \mathrm{dL}$ or personal history of type 2 diabetes mellitus or prescription of hypoglycemic drugs; and (e) High Blood Pressure, $\mathrm{BP} \geq 130 / 85 \mathrm{~mm} / \mathrm{Hg}$ or previously diagnosed hypertension or prescription of antihypertensive drugs.

2.3.8. Assessment of Insulin Resistance. HOMA2-IR was utilized for the evaluation of IR as proposed by Levy et al. [21], computed with the HOMA-Calculator version 2.2.2 software application. IR was defined as HOMA2-IR $\geq 2$ [8].

2.4. Statistical Analysis. Qualitative variables were expressed as absolute and relative frequencies, evaluating association through Pearson's Chi-squared $\left(\chi^{2}\right)$ test, while the $Z$ test for proportions was used to assess differences between proportions. Quantitative variables were evaluated for distribution normality with Geary's test and were expressed as arithmetic means \pm SD. Variables with nonnormal distribution underwent logarithmic transformation; when normalization could not be achieved, these variables were expressed as medians (25th percentile-75th percentile). Student's $t$-test or Mann-Whitney's $U$ tests were applied to evaluate differences between means or medians, respectively. 
TABLE 2: Sociodemographic and psychobiologic characteristics of the population by gender (Maracaibo, Venezuela, 2015).

\begin{tabular}{|c|c|c|c|c|c|c|}
\hline & \multicolumn{2}{|c|}{ Females $(n=1056)$} & \multicolumn{2}{|c|}{ Males $(n=970)$} & \multicolumn{2}{|c|}{ Total $(n=2026)$} \\
\hline & $n$ & $\%$ & $n$ & $\%$ & $n$ & $\%$ \\
\hline \multicolumn{7}{|l|}{ Age groups (years) } \\
\hline$<30$ & 308 & 29.2 & 365 & 37.6 & 673 & 33.2 \\
\hline $30-59$ & 607 & 57.5 & 517 & 53.3 & 1124 & 55.5 \\
\hline$\geq 60$ & 141 & 13.4 & 88 & 9.1 & 229 & 11.3 \\
\hline \multicolumn{7}{|l|}{ Ethnic groups } \\
\hline Mixed & 796 & 75.4 & 754 & 77.7 & 1550 & 76.5 \\
\hline Hispanic white & 175 & 16.6 & 146 & 15.1 & 321 & 15.8 \\
\hline Afro-Venezuelan & 27 & 2.6 & 33 & 3.4 & 60 & 3.0 \\
\hline American Indian & 47 & 4.5 & 36 & 3.7 & 83 & 4.1 \\
\hline Others & 11 & 1.0 & 1 & 0.1 & 12 & 0.6 \\
\hline \multicolumn{7}{|l|}{ Socioeconomic status } \\
\hline Stratum I & 17 & 1.6 & 19 & 2.0 & 36 & 1.8 \\
\hline Stratum II & 179 & 17.0 & 185 & 19.1 & 364 & 18.0 \\
\hline Stratum III & 394 & 37.3 & 409 & 42.2 & 803 & 39.6 \\
\hline Stratum IV & 411 & 38.9 & 325 & 33.5 & 736 & 36.3 \\
\hline Stratum V & 55 & 5.2 & 32 & 3.3 & 87 & 4.3 \\
\hline \multicolumn{7}{|l|}{ Marital status } \\
\hline Single & 445 & 42.3 & 414 & 43.1 & 859 & 42.7 \\
\hline Married & 392 & 37.2 & 417 & 43.4 & 809 & 40.2 \\
\hline Others & 216 & 20.5 & 130 & 13.5 & 346 & 17.2 \\
\hline \multicolumn{7}{|l|}{ Educational status } \\
\hline Illiterate & 25 & 2.4 & 17 & 1.8 & 42 & 2.1 \\
\hline Primary education & 217 & 20.5 & 103 & 10.6 & 320 & 15.8 \\
\hline Secondary education & 466 & 44.1 & 479 & 49.4 & 945 & 46.6 \\
\hline High education & 348 & 33.0 & 371 & 38.2 & 719 & 35.5 \\
\hline \multicolumn{7}{|l|}{ Occupational status } \\
\hline Unemployed & 575 & 54.5 & 263 & 27.1 & 838 & 41.4 \\
\hline Employed & 481 & 45.5 & 707 & 72.9 & 1188 & 58.6 \\
\hline \multicolumn{7}{|l|}{ Smoking habit } \\
\hline Nonsmoker & 792 & 75.1 & 606 & 62.9 & 1398 & 69.3 \\
\hline Current smoker & 119 & 11.3 & 181 & 18.8 & 300 & 14.9 \\
\hline Past smoker & 143 & 13.6 & 177 & 18.4 & 320 & 15.9 \\
\hline Alcohol intake $^{*}(\%)$ & 196 & 18.6 & 470 & 48.5 & 666 & 32.9 \\
\hline Physical inactivity ${ }^{* *}$ (\%) & 252 & 23.9 & 443 & 45.7 & 695 & 34.3 \\
\hline
\end{tabular}

A multiple logistic regression model was constructed in order to estimate odds ratios (confidence interval 95\%) for the presence of IR, adjusted by gender, age groups, ethnic groups, socioeconomic status, educational status, marital status, occupational status, smoking habits, leisure-domain PA, glycemic status, presence of high TAG, presence of low HDLC, JNC-8 classification, presence of elevated WC, and BMI classification. Data were analyzed with the Statistical Package for the Social Sciences (SPSS) version 21 for Windows (IBM Inc., Chicago, IL), and the results were considered statistically significant when $p<0.05$.

\section{Results}

3.1. Characteristics of the General Population. The sociodemographic and psychobiologic features of the sample are summarized in Table 2, while metabolic and anthropometric aspects are presented in Table 3. A total of 2026 individuals were studied: $52.10 \%(n=1056)$ females and $47.90 \%(n=$ 970) males. The mean age was $39.69 \pm 15.37$ years $(41.06 \pm$ 15.68 years for women, $38.20 \pm 14.89$ years for men).

3.2. HOMA2-IR by Gender and Age Groups. The prevalence of IR was $46.5 \%(n=943)$ in the general population, with $46.7 \%(n=493)$ in women and $46.4 \%(n=450)$ in men $\left(\chi^{2}=0.018 ; p=0.895\right)$ (Figure $\left.1(\mathrm{a})\right)$. On the other hand, Figure 1(b) illustrates the prevalence of IR by age groups: A significantly greater proportion of IR was found in the groups aged $30-59$ years $(49.7 \%, n=559)$ and $\geq 60$ years $(49.8 \%, n=$ $114)$, in comparison to individuals aged $<30$ years $(40.1 \%, n=$ 270) $\left(\chi^{2}=16.726 ; p=2.33 \times 10^{-4}\right)$. 
TABLE 3: Anthropometric and cardiometabolic characteristics of the population by gender (Maracaibo, Venezuela, 2015).

\begin{tabular}{|c|c|c|c|c|c|c|}
\hline & \multicolumn{2}{|c|}{ Females $(n=1056)$} & \multicolumn{2}{|c|}{ Males $(n=970)$} & \multicolumn{2}{|c|}{ Total $(n=2026)$} \\
\hline & $n$ & $\%$ & $n$ & $\%$ & $n$ & $\%$ \\
\hline \multicolumn{7}{|l|}{ Body Mass Index $\left(\mathrm{kg} / \mathrm{m}^{2}\right)$} \\
\hline$\leq 24.9$ & 377 & 35.7 & 245 & 25.3 & 622 & 30.7 \\
\hline $25-29.9$ & 333 & 31.5 & 386 & 39.8 & 719 & 35.5 \\
\hline$\geq 30$ & 346 & 32.8 & 339 & 34.9 & 685 & 33.8 \\
\hline \multicolumn{7}{|l|}{ High $T_{A G}^{\ddagger}$} \\
\hline Absent & 815 & 77.2 & 644 & 66.4 & 1459 & 72.0 \\
\hline Present & 241 & 22.8 & 326 & 33.6 & 567 & 28.0 \\
\hline \multicolumn{7}{|l|}{ Low HDL-C $C^{*}$} \\
\hline Absent & 384 & 36.4 & 479 & 49.4 & 863 & 42.6 \\
\hline Present & 672 & 63.6 & 491 & 50.6 & 1163 & 57.4 \\
\hline \multicolumn{7}{|l|}{ Elevated $W C^{*}$} \\
\hline Absent & 597 & 51.0 & 502 & 47.4 & 1099 & 49.3 \\
\hline Present & 573 & 49.0 & 556 & 52.6 & 1129 & 50.7 \\
\hline \multicolumn{7}{|l|}{ JNC-8 classification } \\
\hline Normotensive & 481 & 45.5 & 312 & 32.2 & 793 & 39.1 \\
\hline Prehypertensive & 381 & 36.1 & 384 & 39.6 & 765 & 37.8 \\
\hline Hypertensive & 194 & 18.4 & 274 & 28.2 & 468 & 23.1 \\
\hline \multicolumn{7}{|l|}{ Glycemic status $^{¥}$} \\
\hline Normoglycemic & 775 & 73.5 & 667 & 68.8 & 1442 & 71.2 \\
\hline Impaired fasting glycemia & 187 & 17.7 & 217 & 22.4 & 404 & 20.0 \\
\hline Type 2 diabetes mellitus & 92 & 8.7 & 86 & 8.9 & 178 & 8.8 \\
\hline
\end{tabular}

TAG: triacylglycerides; HDL-C: high-density lipoprotein-cholesterol; WC: waist circumference.

${ }^{\ddagger}$ IDF/AHA/NHLBI/WHF/IAS/IASO 2009 consensus criteria.

${ }^{*}$ Females $\geq 90 \mathrm{~cm}$; males $\geq 95 \mathrm{~cm}$.

${ }^{¥} A D A 2014$ classification.

3.3. HOMA2-IR and Other Sociodemographic Factors. When assessing the epidemiologic behavior of IR according to sociodemographic factors (Table 4 ), an association was found only in regard to marital status $\left(\chi^{2}=17.293, p=0.001\right)$, with a significantly greater proportion of IR subjects among married individuals (51.5\% versus $48.5 \%$ individuals with HOMA2-IR < 2).

3.4. HOMA2-IR and Psychobiologic Habits. Regarding smoking habits (Figure 2(a)), no link was found with the presence of IR $\left(\chi^{2}=6.575 ; p=0.37\right)$. Nevertheless, we observed a greater proportion of IR subjects among past smokers $(51.9 \%$ versus $48.1 \%$ without IR; $p<0.05)$. Conversely, the absence of IR was prevalent among nonsmokers (55.2\% versus $44.8 \%$ with IR; $p<0.05)$. With respect to alcohol intake and IR (Figure 2(b)), no statistically significant association was found $\left(\chi^{2}=3.969 ; p=0.46\right)$. Similarly, no link was ascertained between IR and PA in the home $\left(\chi^{2}=2.27\right.$; $p=0.81)$, work $\left(\chi^{2}=1.82 ; p=0.87\right)$, and transport $\left(\chi^{2}=\right.$ $8.60 ; p=0.12$ ) domains (Table 5). However, a significant association was ascertained between the presence of IR and leisure-domain PA $\left(\chi^{2}=23.24 ; p=0.003\right)$, with a higher proportion of non-IR individuals in the high and very high $\mathrm{PA}$ categories in this domain $(61.3 \%, n=92$ and $65.5 \%$, $n=110$, resp., versus IR subjects; $p<0.05)$.
3.5. HOMA2-IR and Metabolic Characteristics. The presence of HOMA2-IR $\geq 2$ was found to be associated with various metabolic characteristics (Table 6), being significantly more prevalent among subjects with $\mathrm{BMI} \geq 30 \mathrm{~kg} / \mathrm{m}^{2}$ (68.8\% versus $31.2 \%$ in subjects without IR; $p<0.05)$, high TAG $(62.8 \%$ versus $37.2 \%$; $p<0.05)$, low HDL-C (52.5\% versus $47.5 \%$; $p<0.05)$, elevated WC (67.7\% versus 36.3\%; $p<0.05)$, hypertension (57.9\% versus $42.1 \%$; $p<0.05)$, impaired fasting glucose $(37.6 \%$ versus $62.4 \% ; p<0.05)$, and DM2 $(78.7 \%$ versus $21.3 \%$; $p<0.05)$.

3.6. HOMA2-IR and Biologic and Anthropometric Variables. Table 7 displays the behavior of several biologic and anthropometric characteristics by IR status. Individuals with this disorder had significantly higher age $\left(p=3.15 \times 10^{-5}\right)$, BMI $\left(p=13 \times 10^{-5}\right)$, WC $\left(p=4.49 \times 10^{-54}\right)$, fasting blood glucose $\left(p=3.41 \times 10^{-39}\right)$, systolic BP $\left(p=2.33 \times 10^{-8}\right)$, diastolic BP $\left(p=2.93 \times 10^{-11}\right)$, and hs-CRP $\left(p=4.51 \times 10^{-7}\right)$ than the nonIR population. A similar pattern was found regarding serum lipids, especially TAG $(154.48 \pm 122.02$ versus $110.70 \pm 76.27$; IR and non-IR subjects, $p=5.45 \times 10^{-29}$ ) and HDL-C, which was significantly lower in IR individuals $(41.97 \pm 10.95$ versus $\left.45.90 \pm 12.58 ; p=3.67 \times 10^{-14}\right)$.

3.7. Risk Factors for Insulin Resistance in Maracaibo City. The risk factors for the presence of IR in our population are shown 


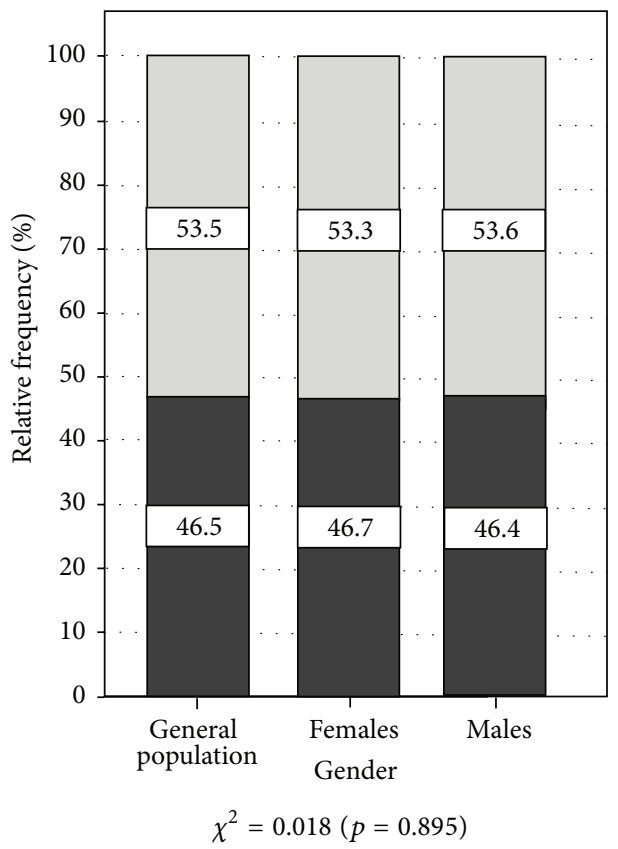

$\square$ HOMA2-IR $<2$

HOMA2-IR $\geq 2$

(a)

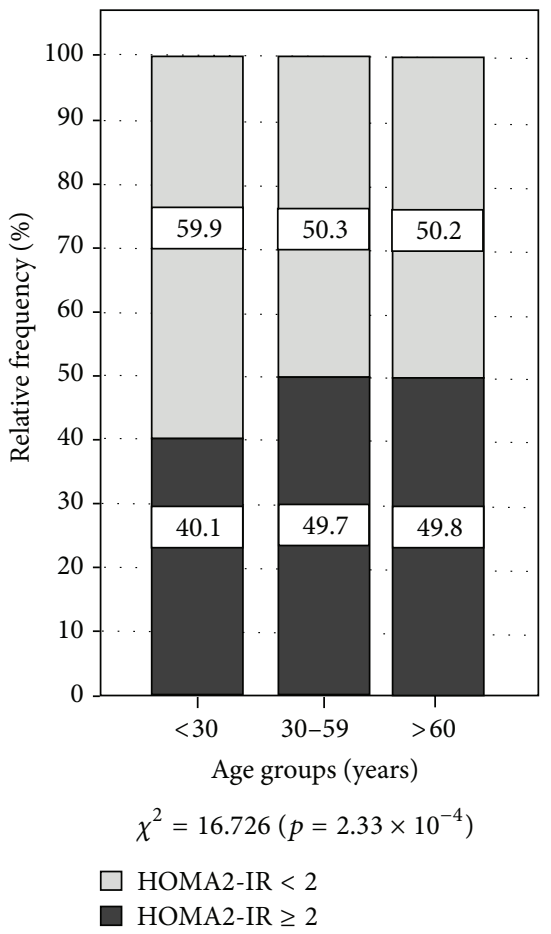

(b)

FIGURE 1: Prevalence of insulin resistance by gender and age groups. Maracaibo, Venezuela. 2014. $Z$ Test for proportions: gender: nonsignificant. Age groups: $<30$ years (HOMA2-IR $<2$ versus HOMA2-IR $\geq 2 ; p<0.05$ ); 30-59 years (HOMA2-IR $\geq 2$ versus HOMA2-IR $<2 ; p<0.05)$.

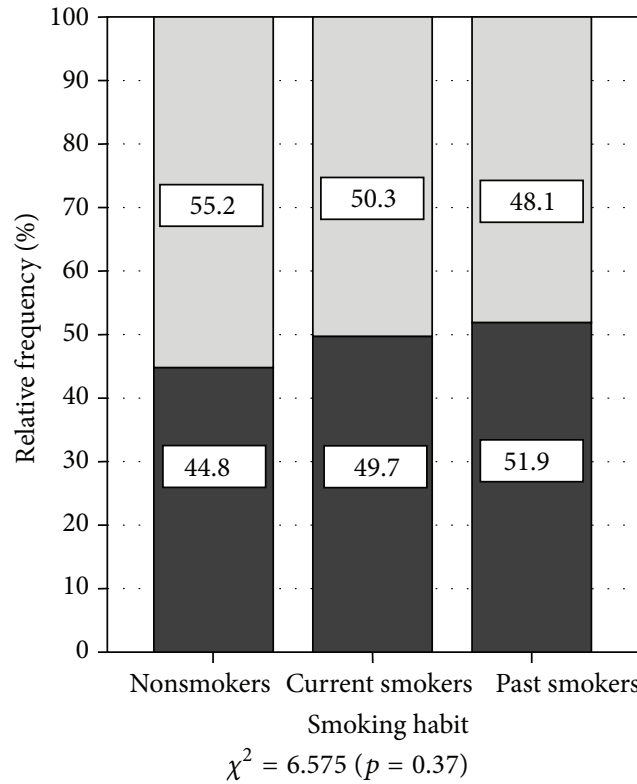

HOMA2-IR $<2$

HOMA2-IR $\geq 2$

(a)

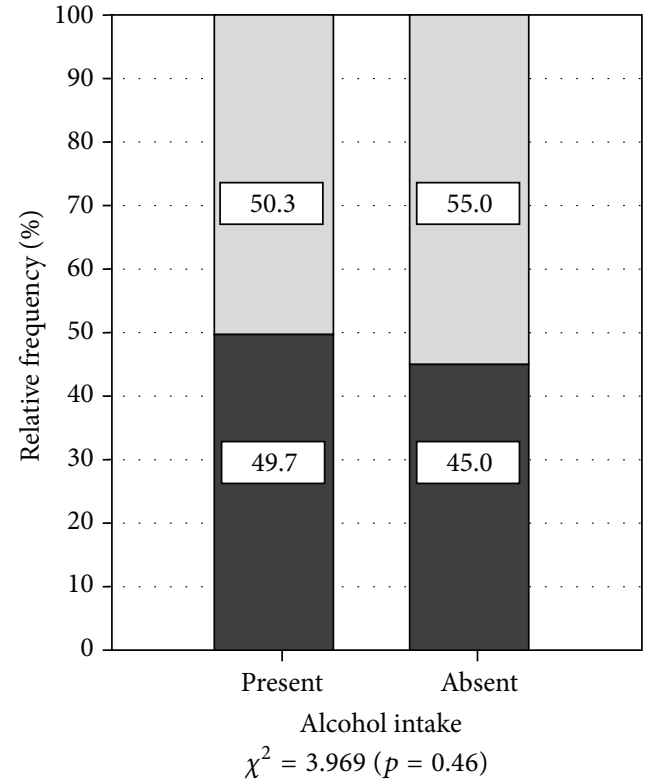

$\square$ HOMA2-IR $<2$

HOMA2-IR $\geq 2$

Figure 2: Prevalence of insulin resistance in the general population by smoking habits and alcohol intake. Maracaibo, Venezuela. 2014. $\chi^{2}$ $=$ Pearson's Chi-squared test. $Z$ test for proportions: smoking habits: nonsmokers (HOMA2-IR $<2$ versus HOMA2-IR $\geq 2$; $p<0.05$ ); past smokers (HOMA2-IR $\geq 2$ versus HOMA2-IR $<2 ; p<0.05$ ). Alcohol intake: present (HOMA2-IR $\geq 2$ versus HOMA2-IR $<2 ; p<0.05$ ); absent (HOMA2-IR $<2$ versus HOMA2-IR $\geq 2 ; p<0.05$ ). 
TABLE 4: Prevalence of insulin resistance in the general population by sociodemographic variables (Maracaibo, Venezuela, 2015).

\begin{tabular}{|c|c|c|c|c|c|c|}
\hline & \multicolumn{2}{|c|}{ HOMA2-IR $<2$} & \multicolumn{2}{|c|}{ HOMA2-IR $\geq 2$} & \multirow{2}{*}{$p^{*}$} & \multirow{2}{*}{$\chi^{2}(p)$} \\
\hline & $n$ & $\%$ & $n$ & $\%$ & & \\
\hline Ethnic group & & & & & & $2.65(0.61)$ \\
\hline Mixed & 837 & 54.0 & 713 & 46.0 & NS & \\
\hline Hispanic white & 161 & 50.2 & 160 & 49.8 & NS & \\
\hline Afro-Venezuelan & 33 & 55.0 & 27 & 45.0 & NS & \\
\hline American Indian & 47 & 56.6 & 36 & 43.4 & NS & \\
\hline Others & 5 & 41.7 & 7 & 58.3 & NS & \\
\hline Socioeconomic status & & & & & & $4.33(0.36)$ \\
\hline Stratum I: High Class & 18 & 50.0 & 18 & 50.0 & NS & \\
\hline Stratum II: Middle-High Class & 186 & 51.1 & 178 & 48.9 & NS & \\
\hline Stratum III: Middle Class & 445 & 55.4 & 358 & 44.6 & NS & \\
\hline Stratum IV: Relative Poverty & 382 & 51.9 & 354 & 48.1 & NS & \\
\hline Stratum V: Critical Poverty & 52 & 59.8 & 35 & 40.2 & NS & \\
\hline Marital status & & & & & & $17.29(0.001)$ \\
\hline Single & 503 & 58.6 & 356 & 41.4 & $<0.05$ & \\
\hline Married & 392 & 48.5 & 417 & 51.5 & $<0.05$ & \\
\hline Others & 181 & 52.3 & 165 & 47.7 & NS & \\
\hline Educational status & & & & & & $6.76(0.079)$ \\
\hline Illiterate & 27 & 64.3 & 15 & 35.7 & NS & \\
\hline Primary education & 154 & 48.1 & 166 & 51.9 & $<0.05$ & \\
\hline Secondary education & 521 & 55.1 & 424 & 44.9 & NS & \\
\hline High education & 381 & 53.0 & 338 & 47.0 & NS & \\
\hline Occupational status & & & & & & $3.25(0.071)$ \\
\hline Unemployed & 428 & 51.1 & 410 & 48,9 & NS & \\
\hline Employed & 655 & 55.1 & 533 & 44.9 & NS & \\
\hline
\end{tabular}

NS: nonsignificant; $p^{*}: Z$ test for proportions; $\chi^{2}:$ Pearson’s Chi-squared test.

in Table 8. Following adjustment of the multivariate model, the age groups of $30-59$ years (OR: 0.65 , CI 95\%: 0.50-0.85; $p<0.01$ ) and $\geq 60$ years (OR: 0.42 , CI 95\%: 0.28-0.65; $p<0.01)$ were associated with lower odds of IR. On the other hand, the female gender (OR: 1.29, CI 95\%: 1.02-1.65; $p=0.04$ ) and employed occupational status (OR: 1.45, CI 95\%: 1.15-1.83; $p<0.01)$ were linked with higher risk of IR. The sole psychobiologic factor independently related to IR was alcohol intake (OR: 1.41, CI 95\%: 1.10-1.79; $p<0.01$ ). Similarly, high TAG (OR: 1.77, CI 95\%: 1.38-2.27; $p<0.01$ ), low HDL-C (OR: 1.31, CI 95\%: 1.06-1.64; $p=0.01$ ), and BMI $\geq 30 \mathrm{~kg} / \mathrm{m}^{2}$ (OR: 4.33, CI 95\%: 2.97-6.29; $p<0.01$ ), as well as impaired fasting glucose and DM2, were also associated with increased odds of IR in our population. Furthermore, no relevant differences were revealed after adjustment of a second model with exclusion of diabetic subjects.

\section{Discussion}

In recent years, a myriad of biologic, psychological, sociodemographic, and economic factors have driven the epidemiologic transition, which features a shift in the major worldwide causes of mortality from infectious diseases to chronicdegenerative disorders [22]. This group includes cardiovascular disease and DM2, where IR plays a fundamental role in their pathophysiology, in close association with Westernized lifestyles such as physical inactivity and hypercaloric diets [1]. Thus, detection and management of this condition have become a priority in primary care. Nevertheless, its epidemiologic behavior remains incompletely elucidated in many populations, including our locality.

We found the prevalence of IR in Maracaibo to be relatively elevated, in harmony with other reports within our country, 54.8\% in Valencia city [23], 50.6\% in a community from Tinaquillo [24], and up to $61.2 \%$ in a CanarianVenezuelan population [25]. This may be explained by the growing prevalence of obesity and other cardiovascular risk factors in Venezuela [26], as well as methodological limitations and heterogeneity.

Moreover, IR prevalence is widely variable across demographics: whereas European populations appear to boast lower prevalence of IR, estimated at $17 \%$ in a Danish study, for example, [27], it has been reported to be as high as $51 \%$ in Iran, West Asia [28]. On the other hand, IR prevalence has been estimated at $39.1 \%$ in Hispanic subjects residing in Texas, USA [29]. Indeed, differing genetic, epigenetic, and sociocultural factors are important determinants of insulin sensitivity [30, 31]. In addition, utilization of IR-assessing methods different from HOMA2-IR or arbitrary cutoffs may also contribute to these disparities [32]. 
TABLE 5: Prevalence of insulin resistance in the general population by physical activity domains (Maracaibo, Venezuela, 2015).

\begin{tabular}{|c|c|c|c|c|c|c|}
\hline \multirow{2}{*}{ Physical activity pattern } & \multicolumn{2}{|c|}{ HOMA2-IR $<2$} & \multicolumn{2}{|c|}{ HOMA2-IR $\geq 2$} & \multirow{2}{*}{$p^{*}$} & \multirow{2}{*}{$\chi^{2}(p)$} \\
\hline & $n$ & $\%$ & $n$ & $\%$ & & \\
\hline Work domain & & & & & & $1.82(0.87)$ \\
\hline Inactive & 799 & 53.1 & 706 & 46.9 & NS & \\
\hline Very low & 56 & 53.8 & 48 & 46.2 & NS & \\
\hline Low & 63 & 58.9 & 44 & 41.1 & NS & \\
\hline Moderate & 52 & 51.0 & 50 & 49.0 & NS & \\
\hline High & 54 & 52.9 & 48 & 47.1 & NS & \\
\hline Very high & 59 & 55.7 & 47 & 44.3 & NS & \\
\hline Transport domain & & & & & & $8.60(0.12)$ \\
\hline Inactive & 359 & 49.3 & 369 & 50.7 & NS & \\
\hline Very low & 129 & 56.3 & 100 & 43.7 & NS & \\
\hline Low & 147 & 56.1 & 115 & 43.9 & NS & \\
\hline Moderate & 142 & 55.5 & 114 & 44.5 & NS & \\
\hline High & 161 & 57.1 & 121 & 42.9 & NS & \\
\hline Very high & 132 & 54.8 & 109 & 45.2 & NS & \\
\hline Household domain & & & & & & $2.27(0.81)$ \\
\hline Inactive & 295 & 52.2 & 270 & 47.8 & NS & \\
\hline Very low & 151 & 55.7 & 120 & 44.3 & NS & \\
\hline Low & 160 & 53.5 & 139 & 46.5 & NS & \\
\hline Moderate & 172 & 56.2 & 134 & 43.8 & NS & \\
\hline High & 148 & 52.5 & 134 & 47.5 & NS & \\
\hline Very high & 157 & 51.8 & 146 & 48.2 & NS & \\
\hline Leisure domain & & & & & & $23.24(0.003)$ \\
\hline Inactive & 612 & 50.0 & 613 & 50.0 & NS & \\
\hline Very low & 79 & 50.3 & 78 & 49.7 & NS & \\
\hline Low & 98 & 57.6 & 72 & 42.4 & NS & \\
\hline Moderate & 92 & 59.0 & 64 & 41.0 & NS & \\
\hline High & 92 & 61.3 & 58 & 38.7 & $<0.05$ & \\
\hline Very high & 110 & 65.5 & 58 & 34.5 & $<0.05$ & \\
\hline
\end{tabular}

NS: nonsignificant; $\chi^{2}$ : Pearson's Chi-squared test; $p^{*}: Z$ test for proportions.

In our sample, IR prevalence was similar between genders, diverging from findings in a Danish population [27] and the Framingham Heart Study [33], where men showed a higher prevalence, ostensibly attributed to the protective role of estrogens in the development of IR [34]. However, in our study, multivariate analysis revealed women to be at greater risk of IR, echoing a previous report by Rojas et al. [35] on subjects with acute coronary syndrome from Maracaibo. Furthermore, it should be noted that, in this study, the average age in females was 41 years, when a progressive decline in ovarian function tends to begin in most women [36]. In addition, females older than this average age displayed greater prevalence of DM2 and physical inactivity than their male counterparts; these factors favor endocrine-metabolic aging [37] which may explain our findings.

Indeed, aging has been closely linked with IR, chiefly due to the loss of lean mass and gain of visceral adiposity seen in this process [38]. Nonetheless, in multivariate analysis, we found individuals aged $\geq 60$ years to have lower odds of IR. In this regard, certain reports have outlined a protective or innocuous role for adiposity in old age, due to reduced lipolytic activity in this tissue [39]. Likewise, in subjects with chronic-degenerative diseases, a BMI $\geq 25 \mathrm{Kg} / \mathrm{m}^{2}$ has been reported to be linked with lower mortality, in a phenomenon termed the "obesity paradox" [40, 41]. This effect may be responsible for the lower prevalence of IR in our study, as subjects aged $\geq 60$ years exhibited high prevalence of abdominal obesity and comorbidities such as DM2, metabolic syndrome, and hypertension. At any rate, this relationship is very complex with numerous confounding factors, for example, smoking habits, and other comorbidities; therefore, future studies should further explore the interplay between obesity, IR, and old age.

When examining sociodemographic factors, we found marital status to be associated with IR, which was more frequent among married subjects. Notably, a large part of these were male, were inactive, and had elevated BMI and WC, possibly underlying this epidemiologic behavior. This harmonizes with the research by Sobal et al. [42] and Kiadaliri et al. [43] who described married men to have increased risk of overweight and obesity, associated with more frequent and abundant eating and decreased PA. Occupational status also 
TABLE 6: Prevalence of insulin resistance in the general population by metabolic characteristics (Maracaibo, Venezuela, 2015).

\begin{tabular}{|c|c|c|c|c|c|c|}
\hline & \multicolumn{2}{|c|}{ HOMA2-IR $<2$} & \multicolumn{2}{|c|}{ HOMA2-IR $\geq 2$} & \multirow{2}{*}{$p^{*}$} & \multirow{2}{*}{$\chi^{2}(p)$} \\
\hline & $n$ & $\%$ & $n$ & $\%$ & & \\
\hline Body Mass Index $\left(\mathrm{kg} / \mathrm{m}^{2}\right)$ & & & & & & $232.022(<0.001)$ \\
\hline$\leq 24.9$ & 456 & 73.3 & 166 & 26.7 & $<0.05$ & \\
\hline $25-29.9$ & 409 & 57.4 & 305 & 42.6 & $<0.05$ & \\
\hline$\geq 30$ & 214 & 31.2 & 469 & 68.8 & $<0.05$ & \\
\hline High $\mathrm{TAG}^{\ddagger}$ & & & & & & $83.47\left(5.42 \times 10^{-20}\right)$ \\
\hline Absent & 872 & 59.8 & 587 & 40.2 & $<0.05$ & \\
\hline Present & 211 & 37.2 & 356 & 62.8 & $<0.05$ & \\
\hline Low HDL-C & & & & & & $38.27\left(6.15 \times 10^{-10}\right)$ \\
\hline Absent & 530 & 61.4 & 333 & 38.6 & $<0.05$ & \\
\hline Present & 553 & 47.5 & 610 & 52.5 & $<0.05$ & \\
\hline Elevated $W C^{*}$ & & & & & & $198.75(<0.001)$ \\
\hline Absent & 689 & 63.7 & 304 & 32.3 & $<0.05$ & \\
\hline Present & 393 & 36.3 & 638 & 67.7 & $<0.05$ & \\
\hline JNC-8 classification & & & & & & $42.83(<0.001)$ \\
\hline Normotensive & 484 & 61 & 309 & 39 & $<0.05$ & \\
\hline Prehypertensive & 402 & 52.5 & 363 & 47.5 & NS & \\
\hline Hypertensive & 197 & 42.1 & 271 & 57.9 & $<0.05$ & \\
\hline Glycemic status $^{¥}$ & & & & & & $155.37(<0.001)$ \\
\hline Normoglycemic & 892 & 61.9 & 550 & 38.1 & $<0.05$ & \\
\hline Impaired fasting glycemia & 152 & 37.6 & 252 & 62.4 & $<0.05$ & \\
\hline Type 2 diabetes mellitus & 38 & 21.3 & 140 & 78.7 & $<0.05$ & \\
\hline
\end{tabular}

${ }^{*} Z$ test for proportions; $\chi^{2}$ : Pearson's Chi-squared test.

TAG: triacylglycerides; HDL-C: high-density lipoprotein-cholesterol; WC: waist circumference.

${ }^{\ddagger}$ IDF/AHA/NHLBI/WHF/IAS/IASO 2009 consensus criteria.

*Females $\geq 90 \mathrm{~cm}$; males $\geq 95 \mathrm{~cm}$.

${ }^{¥} A D A 2014$ classification.

TABLE 7: Biologic and anthropometric characteristics in the general population by insulin resistance status (Maracaibo, Venezuela, 2015).

\begin{tabular}{|c|c|c|c|}
\hline & HOMA2-IR < $2(n=1083)$ & HOMA2-IR $\geq 2(n=943)$ & $p^{*}$ \\
\hline Age (years) ${ }^{\mathrm{a}}$ & $38.48 \pm 15.50$ & $41.09 \pm 15.11$ & $3.15 \times 10^{-5}$ \\
\hline Body Mass Index $\left(\mathrm{kg} / \mathrm{m}^{2}\right)^{\mathrm{a}}$ & $26.39 \pm 5.24$ & $30.60 \pm 6.52$ & $7.13 \times 10^{-55}$ \\
\hline Waist circumference $(\mathrm{cm})^{\mathrm{a}}$ & $89.92 \pm 12.68$ & $100.34 \pm 16.6$ & $4.49 \times 10^{-54}$ \\
\hline Fasting glycemia $(\mathrm{mg} / \mathrm{dL})^{\mathrm{a}}$ & $91.88 \pm 20.99$ & $107.48 \pm 50.78$ & $3.41 \times 10^{-39}$ \\
\hline Fasting insulin $(\mu \mathrm{U} / \mathrm{mL})^{\mathrm{a}}$ & $8.80 \pm 2.70$ & $21.46 \pm 10.15$ & $<0.001$ \\
\hline HOMA2-IR & $1.31 \pm 0.40$ & $3.24 \pm 1.47$ & $<0.001$ \\
\hline Total cholesterol $(\mathrm{mg} / \mathrm{dL})^{\mathrm{a}}$ & $186.91 \pm 45.67$ & $196.87 \pm 46.31$ & $2.39 \times 10^{-7}$ \\
\hline Triacylglycerides $(\mathrm{mg} / \mathrm{dL})^{\mathrm{a}}$ & $110.70 \pm 76.27$ & $154.48 \pm 122.02$ & $5.45 \times 10^{-29}$ \\
\hline $\mathrm{LDL}-\mathrm{C}(\mathrm{mg} / \mathrm{dL})^{\mathrm{a}}$ & $118.80 \pm 38.06$ & $125.25 \pm 38.84$ & $<0.001$ \\
\hline $\mathrm{HDL}-\mathrm{C}(\mathrm{mg} / \mathrm{dL})^{\mathrm{a}}$ & $45.90 \pm 12.58$ & $41.97 \pm 10.95$ & $3.67 \times 10^{-14}$ \\
\hline Systolic BP (mmHg) ${ }^{\mathrm{a}}$ & $117.91 \pm 16.57$ & $121.96 \pm 17.08$ & $2.33 \times 10^{-8}$ \\
\hline Diastolic BP $(\mathrm{mmHg})^{\mathrm{a}}$ & $75.75 \pm 10.99$ & $79.05 \pm 11.44$ & $2.93 \times 10^{-11}$ \\
\hline hs-CRP (mg/dL) ${ }^{b}$ & $0.313(0.086-0.622)$ & $0.420(0.154-0.942)$ & $4.51 \times 10^{-7}$ \\
\hline
\end{tabular}

LDL-C: low-density lipoprotein-cholesterol; HDL-C: high-density lipoprotein-cholesterol; BP: blood pressure; hs-CRP: High-Sensitivity C-Reactive Protein. ${ }^{a}$ Normally distributed variable, expressed as mean \pm standard deviation; ${ }^{b}$ nonnormally distributed variable, expressed as median (25th percentile-75th percentile).

${ }^{*}$ Student's $t$-test was used for normally distributed variables; Mann-Whitney $U$ test was used for nonnormally distributed variables. 
TABLE 8: Sociodemographic and metabolic risk factors associated with insulin resistance (Maracaibo, Venezuela, 2015).

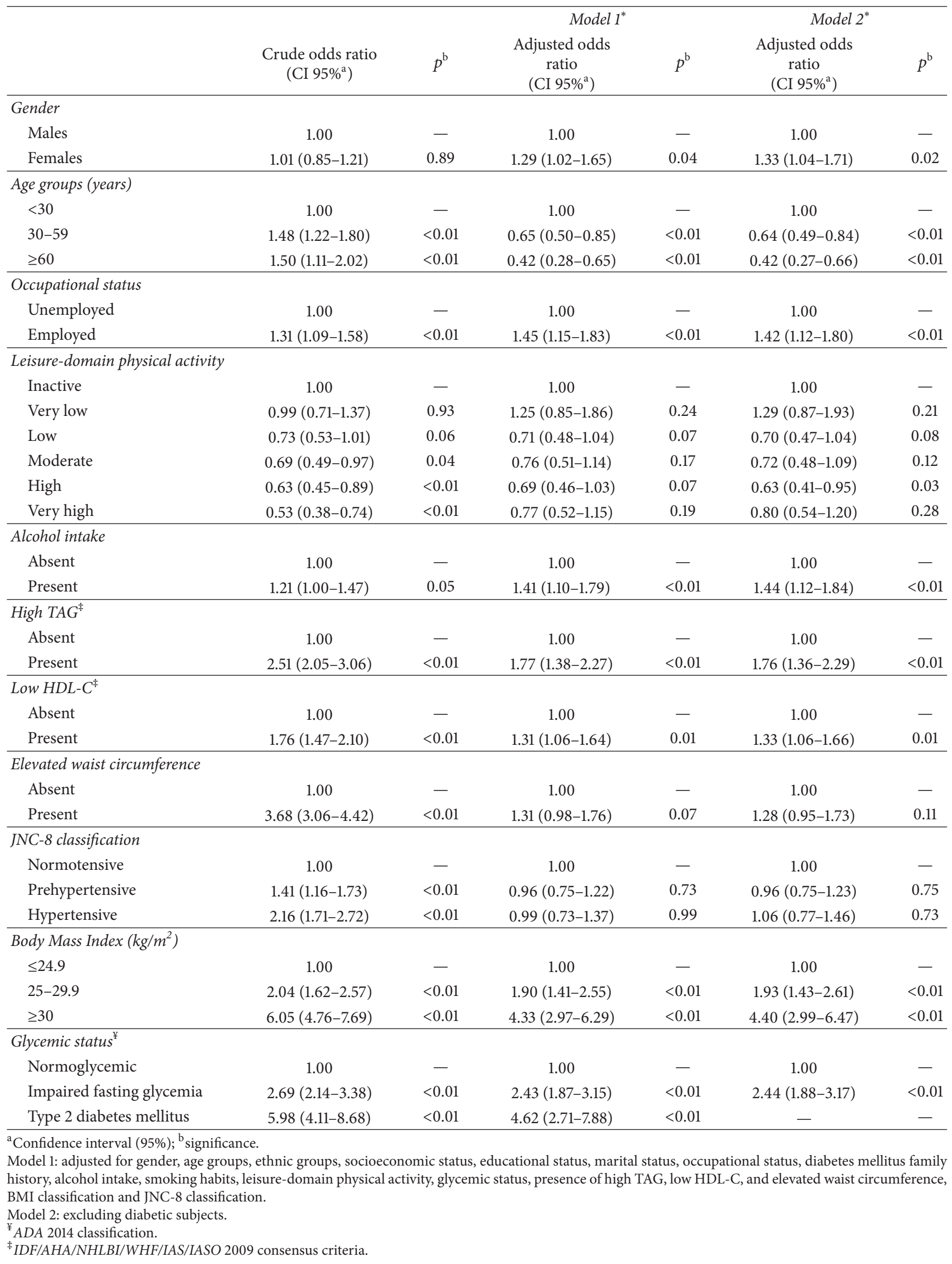


displayed an interesting relationship with IR in our study, with employed individuals having increased odds for this condition. In this context, unemployed subjects exhibited higher leisure-domain $\mathrm{PA}$, along with lower prevalence of elevated WC than their counterparts, in consonance with findings in an Iranian population where unemployment was a protective factor against overweight and obesity [43].

On the other hand, performance of any degree of leisure-domain PA, even under the recommended threshold, has been described to reduce global, cardiovascular, and cancer-related mortality [44], accompanied by a favorable impact on insulin sensitivity and glucose tolerance [45]. We found leisure-domain PA to be a protective factor against IR in males with $>297 \mathrm{MET} /$ week and females with >231 MET/week; thus, the American Diabetes Association recommendations on $\mathrm{PA}$ intensity and quantity may be applicable for prevention of DM2 in Maracaibo [46].

Alcohol consumption was found to be another risk factor for IR in our population. In a previous publication [14], we reported $45 \%$ of men and $16.7 \%$ of women in Maracaibo to be habitual drinkers; of these, $72.4 \%$ and $76.2 \%$ were shown to drink approximately $1-4$ beers daily with a high prevalence of abdominal obesity in this group. In this respect, a metaanalysis by Bendsen et al. [47] encompassing 35 observational studies and 12 experimental studies determined high beer intake ( $>500 \mathrm{~mL} /$ day) to be associated with abdominal obesity, which in turn plays a central role in the development of IR.

We also found each of the separate components of the metabolic syndrome to be independently associated with IR, with the exception of hypertension. The relationship with obesity appears most prominent: In our population, BMI $\geq$ $30 \mathrm{~kg} / \mathrm{m}^{2}$ grants 4 times greater odds of IR; this link has been extensively demonstrated in several cross-sectional and longitudinal studies [48, 49]. Similarly, high TAG has been associated with decreased insulin sensitivity [50], and both this disorder and low HDL-C have been independently linked with IR [51]. However, in our population, the mild association between elevated WC and IR appears to be dependent on the presence of DM2.

As may be expected, we also found high odds of IR in subjects with hyperglycemia; in this state, oxidation of fatty acids is attenuated, favoring their esterification and leading to a subsequent increase in synthesis of adipokines, which disrupt insulin activity and peripheral utilization of glucose [52]. In parallel, hyperglycemia potentiates oxidative stress via activation of the ceramide and diacylglycerol pathways and other intermediaries, which also hinder insulin signaling [53].

Our results show a close relationship between IR and various sociodemographic, psychobiologic, and cardiometabolic factors in our population, highlighting the clinician's role in the early detection of this condition. Indeed, regardless of the methods employed [54], identification of subjects at high cardiometabolic risk is a fundamental preventive strategy for reducing the morbidity and mortality of disorders associated with IR.

\section{Competing Interests}

The authors have are no conflict of interests to disclose.

\section{Acknowledgments}

This work was supported by Research Grant no. CC-0437-1021-09-10 from Consejo de Desarrollo Científico, Humanístico y Tecnológico (CONDES), University of Zulia, and Research Grant no. FZ-0058-2007 from Fundacite-Zulia.

\section{References}

[1] M. Kasuga, "Insulin resistance and pancreatic $\beta$ cell failure," Journal of Clinical Investigation, vol. 116, no. 7, pp. 1756-1760, 2006.

[2] S. Costes, R. Langen, T. Gurlo, A. V. Matveyenko, and P. C. Butler, " $\beta$-Cell failure in type 2 diabetes: a case of asking too much of too few?" Diabetes, vol. 62, no. 2, pp. 327-335, 2013.

[3] World Health Organization, "The top ten causes of death," Fact Sheet No 310, 2011, http://www.who.int/mediacentre/factsheets/fs310/en/.

[4] J. P. Boyle, T. J. Thompson, E. W. Gregg, L. E. Barker, and D. F. Williamson, "Projection of the year 2050 burden of diabetes in the US adult population: dynamic modeling of incidence, mortality, and prediabetes prevalence," Population Health Metrics, vol. 8, p. 29, 2010.

[5] M. Serrano Ríos, "Resistencia a la insulina y su implicación en múltiples factores de riesgo asociados a diabetes tipo 2," Medicina Clínica, vol. 119, no. 12, pp. 458-463, 2002.

[6] J. Rojas, V. Bermúdez, E. Leal et al., "Insulinorresistencia e hiperinsulinemia como factores de riesgo para enfermedad cardiovascular," Archivos Venezolanos de Farmacología y Terapéutica, vol. 27, no. 1, pp. 29-39, 2008.

[7] D. R. Matthews, J. P. Hosker, A. S. Rudenski, B. A. Naylor, D. F. Treacher, and R. C. Turner, "Homeostasis model assessment: insulin resistance and $\beta$-cell function from fasting plasma glucose and insulin concentrations in man," Diabetologia, vol. 28, no. 7, pp. 412-419, 1985.

[8] V. Bermúdez, J. Rojas, M. S. Martínez et al., "Epidemiologic behavior and estimation of an optimal cut-off point for homeostasis model assessment- 2 insulin resistance: a report from a Venezuelan population," International Scholarly Research Notices, vol. 2014, Article ID 616271, 10 pages, 2014.

[9] V. Bermúdez, R. P. Marcano, C. Cano et al., "The maracaibo city metabolic syndrome prevalence study: design and scope," American Journal of Therapeutics, vol. 17, no. 3, pp. 288-294, 2010.

[10] H. Méndez and M. Méndez, "Estratificación social y biología humana: método Graffar modificado," Archivos Venezolanos de Puericultura y Pediatría, vol. 49, pp. 93-104, 1986.

[11] I. Berlin, S. Lin, J. A. C. Lima, and A. G. Bertoni, "Smoking status and metabolic syndrome in the multi-ethnic study of atherosclerosis. A Cross-Sectional Study," Tobacco Induced Diseases, vol. 10, no. 1, article 9, 2012.

[12] L. Baglietto, D. R. English, J. L. Hopper, J. Powles, and G. G. Giles, "Average volume of alcohol consumed, type of beverage, drinking pattern and the risk of death from all causes," Alcohol and Alcoholism, vol. 41, no. 6, pp. 664-671, 2006. 
[13] A. Martín Centeno and P. Rojano Capilla, "Conceptos y anamnesis del consumo de alcohol en la consulta de Atención Primaria," Medicina General, vol. 29, pp. 957-962, 2000.

[14] V. Berm·dez, Y. Torres, V. Apruzzese et al., "Alcohol drinking patterns in the adult population from the Maracaibo municipality, Zulia-Venezuela," Revista Latinoamericana de Hipertensión, vol. 9, pp. 21-28, 2014.

[15] IPAQ Core Group 2005, "Guidelines for Data Processing and Analysis of the International Physical Activity Questionnaire (IPAQ)-Short and Long Forms," 2015, https://www.researchgate .net/file.PostFileLoader.html?id=56f92d66615e27d49a658031\& assetKey=AS\%3A344600888791041\%401459170662924.

[16] P. A. James, S. Oparil, B. L. Carter et al., "2014 Evidence-based guideline for the management of high blood pressure in adults: report from the panel members appointed to the Eighth Joint National Committee (JNC 8)," The Journal of the American Medical Association, vol. 311, no. 5, pp. 507-520, 2014.

[17] World Health Organization, The World Health Report 2003, World Health Organization, Geneva, Switzerland, 2003, http://www.who.int/topics/obesity/en/.

[18] Health Statistics, NHANES III Reference Manuals and Reports (CDROM), Centers for Disease Control and Prevention, Hyattsville, Md, USA, 1996, http://www.cdc.gov/nchs/data/ nhanes/nhanes3/cdrom/nchs/manuals/anthro.pdf.

[19] W. T. Friedewald, R. I. Levy, and D. S. Fredrickson, "Estimation of the concentration of low-density lipoprotein cholesterol in plasma, without use of the preparative ultracentrifuge," Clinical Chemistry, vol. 18, no. 6, pp. 499-502, 1972.

[20] K. G. M. M. Alberti, R. H. Eckel, S. M. Grundy et al., "Harmonizing the metabolic syndrome: a joint interim statement of the International Diabetes Federation Task Force on Epidemiology and Prevention; National Heart, Lung, and Blood Institute; American Heart Association; World Heart Federation; International Atherosclerosis Society; and International Association for the Study of Obesity," Circulation, vol. 120, no. 16, pp. 1640$1645,2009$.

[21] J. C. Levy, D. R. Matthews, and M. P. Hermans, "Correct homeostasis model assessment (HOMA) evaluation uses the computer program," Diabetes Care, vol. 21, no. 12, pp. 2191-2192, 1998.

[22] A. R. Omran, "The epidemiologic transition: a theory of the epidemiology of population change," Milbank Quarterly, vol. 83, no. 4, pp. 731-757, 2005.

[23] N. Ruiz-Fernández, M. Espinoza, E. Barrios, and A. Reigosa, "Factores cardiometabólicos en una comunidad de Valencia, Venezuela," Revista de Salud Pública, vol. 11, pp. 383-394, 2009.

[24] M. Querales, S. Rojas, G. Quevedo, J. Remolina, O. Mundaray, and D. Graterol, "Cintura hipertrigliceridémica y resistencia a la insulina en una comunidad rural y una urbana de Tinaquillo," Revista Venezolana de Endocrinología y Metabolismo, vol. 12, no. 1, pp. 25-33, 2014.

[25] V. Miguel, Z. Rodríguez, L. Aponte et al., "Insulinorresistencia, obesidad y síndrome metabólico," Cohorte CDC de Canarias en Venezuela. Salus, vol. 17, pp. 18-24, 2013.

[26] H. Schargrodsky, R. Hernández-Hernández, B. M. Champagne et al., "CARMELA: assessment of cardiovascular risk in seven Latin American Cities," The American Journal of Medicine, vol. 121, no. 1, pp. 58-65, 2008.

[27] N. Friedrich, B. Thuesen, T. Jrøgensen et al., "The association between IGF-I and insulin resistance: a general population study in Danish adults," Diabetes Care, vol. 35, no. 4, pp. 768773, 2012.
[28] A. Ziaee, N. Esmailzadehha, S. Oveisi, A. Ghorbani, and L. Ghanei, "The threshold value of homeostasis model assessment for insulin resistance in Qazvin Metabolic Diseases Study (QMDS): assessment of metabolic syndrome," Journal of Research in Health Sciences, vol. 15, no. 2, pp. 94-100, 2015.

[29] H.-Q. Qu, Q. Li, A. R. Rentfro, S. P. Fisher-Hoch, and J. B. McCormick, "The definition of insulin resistance using HOMAIR for americans of mexican descent using machine learning," PLoS ONE, vol. 6, no. 6, Article ID e21041, 2011.

[30] H.-Q. Qu, Q. Li, Y. Lu, C. L. Hanis, S. P. Fisher-Hoch, and J. B. Mccormick, "Ancestral effect on HOMA-IR levels quantitated in an american population of Mexican origin," Diabetes Care, vol. 35, no. 12, pp. 2591-2593, 2012.

[31] S. M. Haffner, R. D’Agostino Jr., M. F. Saad et al., "Increased insulin resistance and insulin secretion in nondiabetic AfricanAmericans and Hispanics compared with non-Hispanic whites: the Insulin Resistance Atherosclerosis Study," Diabetes, vol. 45, no. 6, pp. 742-748, 1996.

[32] T. M. Wallace, J. C. Levy, and D. R. Matthews, "Use and abuse of HOMA modeling," Diabetes Care, vol. 27, no. 6, pp. 1487-1495, 2004.

[33] S. R. Preis, J. M. Massaro, S. J. Robins et al., "Abdominal subcutaneous and visceral adipose tissue and insulin resistance in the framingham heart study," Obesity, vol. 18, no. 11, pp. 2191$2198,2010$.

[34] Z. Suba, "Low estrogen exposure and/or defective estrogen signaling induces disturbances in glucose uptake and energy expenditure," Journal of Diabetes \& Metabolism, vol. 4, no. 5, article 272, 2013.

[35] G. Rojas, Z. Morillo, J. Salazar, L. Bello, R. Añez, and R. Varela, "Insulinorresistencia en pacientes con síndrome coronario agudo: estudio exploratorio del Hospital General del Sur de Maracaibo," Avances Cardiológicos, vol. 34, pp. 202-216, 2014.

[36] J. Rojas, M. Chávez-Castillo, L. C. Olivar et al., "Physiologic course of female reproductive function: a molecular look into the prologue of life," Journal of Pregnancy, vol. 2015, Article ID 715735, 21 pages, 2015.

[37] V. De Tata, "Age-related impairment of pancreatic beta-cell function: pathophysiological and cellular mechanisms," Frontiers in Endocrinology, vol. 5, article 138, 2014.

[38] E. Bonora, G. Formentini, F. Calcaterra et al., "HOMAestimated insulin resistance is an independent predictor of cardiovascular disease in type 2 diabetic subjects: prospective data from the Verona Diabetes Complications Study," Diabetes Care, vol. 25, no. 7, pp. 1135-1141, 2002.

[39] J. C. Seidell and T. L. S. Visscher, "Body weight and weight change and their health implications for the elderly," European Journal of Clinical Nutrition, vol. 54, no. 3, pp. S33-S39, 2000.

[40] K. Kalantar-Zadeh, E. Streja, C. P. Kovesdy et al., “The obesity paradox and mortality associated with surrogates of body size and muscle mass in patients receiving hemodialysis," Mayo Clinic Proceedings, vol. 85, no. 11, pp. 991-1001, 2010.

[41] J. Curtis, J. Selter, and Y. Wang, "The obesity paradox body mass index and outcomes in patients with heart failure," ACC Current Journal Review, vol. 14, no. 4, p. 36, 2005.

[42] J. Sobal, B. S. Rauschenbach, and E. A. Frongillo Jr., "Marital status, fatness and obesity," Social Science \& Medicine, vol. 35, no. 7, pp. 915-923, 1992.

[43] A. A. Kiadaliri, M. Jafari, M.-R. Vaez Mahdavi, S. Faghihzadeh, N. Kalantari, and M. Asadi-Lari, "The prevalence of adulthood overweight and obesity in Tehran: findings from Urban 
HEART-2 study," Medical Journal of the Islamic Republic of Iran, vol. 29, article 178, 2015.

[44] H. Arem, S. C. Moore, A. Patel et al., "Leisure time physical activity and mortality: a detailed pooled analysis of the doseresponse relationship," JAMA Internal Medicine, vol. 175, no. 6, pp. 959-967, 2015.

[45] R. K. Nelson, J. F. Horowitz, R. G. Holleman et al., "Daily physical activity predicts degree of insulin resistance: a crosssectional observational study using the 2003-2004 National Health and Nutrition Examination Survey," International Journal of Behavioral Nutrition and Physical Activity, vol. 10, article 10, 2013.

[46] "Standards of medical care in diabetes-2015: summary of revisions," Diabetes Care, vol. 38, supplement 1, article S4, 2015.

[47] N. T. Bendsen, R. Christensen, E. M. Bartels et al., "Is beer consumption related to measures of abdominal and general obesity? A systematic review and meta-analysis," Nutrition Reviews, vol. 71, no. 2, pp. 67-87, 2013.

[48] M. R. Carnethon, S. P. Fortmann, L. Palaniappan, B. B. Duncan, M. I. Schmidt, and L. E. Chambless, "Risk factors for progression to incident hyperinsulinemia: The Atherosclerosis Risk in Communities Study, 1987-1998," American Journal of Epidemiology, vol. 158, no. 11, pp. 1058-1067, 2003.

[49] S. M. Furler, A. M. Poynten, A. D. Kriketos et al., "Independent influences of central fat and skeletal muscle lipids on insulin sensitivity," Obesity Research, vol. 9, no. 9, pp. 535-543, 2001.

[50] R. P. Hoffman, "Increased fasting triglyceride levels are associated with hepatic insulin resistance in caucasian but not African-American adolescents," Diabetes Care, vol. 29, no. 6, pp. 1402-1404, 2006.

[51] A. Laws and G. M. Reaven, "Evidence for an independent relationship between insulin resistance and fasting plasma HDLcholesterol, triglyceride and insulin concentrations," Journal of Internal Medicine, vol. 231, no. 1, pp. 25-30, 1992.

[52] M. H. deCarvalho, A. L. Colaço, and Z. B. Fortes, "Citocinas, disfunção endotelial e resistência à insulina," Arquivos Brasileiros de Endocrinologia \& Metabologia, vol. 50, no. 2, pp. 304-312, 2006.

[53] D. M. Muoio and C. B. Newgard, "Molecular and metabolic mechanisms of insulin resistance and $\beta$-cell failure in type 2 diabetes," Nature Reviews Molecular Cell Biology, vol. 9, no. 3, pp. 193-205, 2008.

[54] Y. Castillo-Nuñez and C. A. Aguilar-Salina, "Medición de la resistencia a la insulina en la práctica clínica," Revista $A L A D$, vol. 5, pp. 8-10, 2015. 


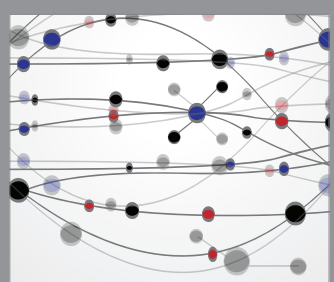

The Scientific World Journal
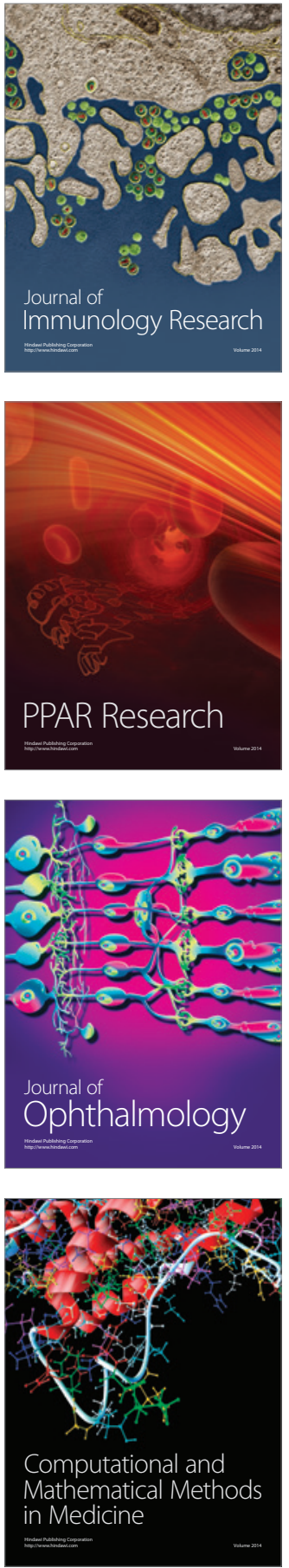

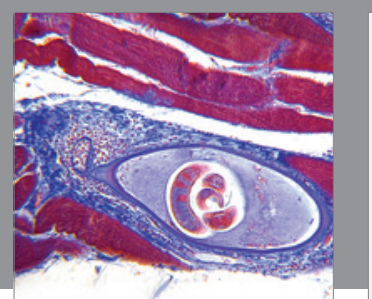

Gastroenterology Research and Practice

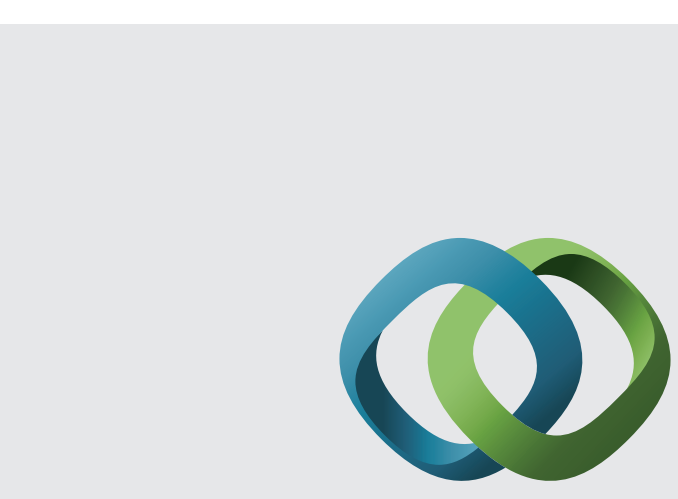

\section{Hindawi}

Submit your manuscripts at

http://www.hindawi.com
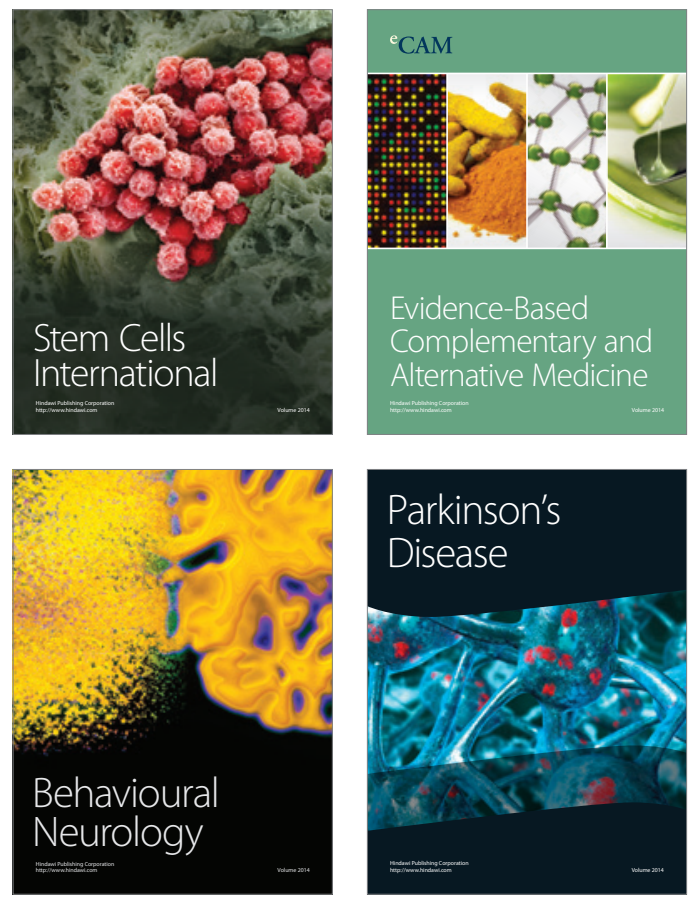
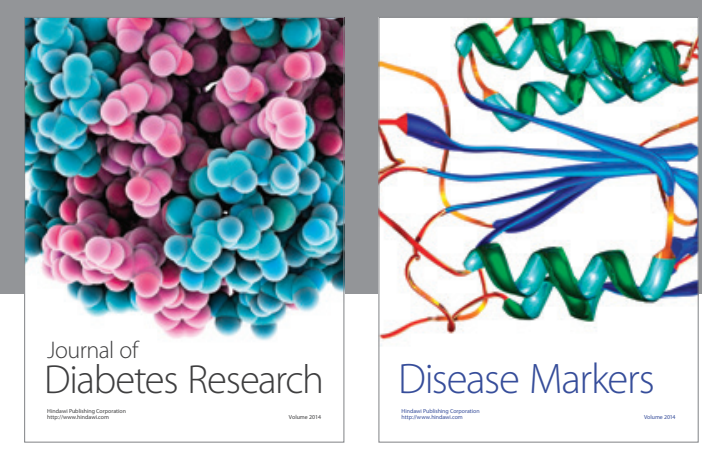

Disease Markers
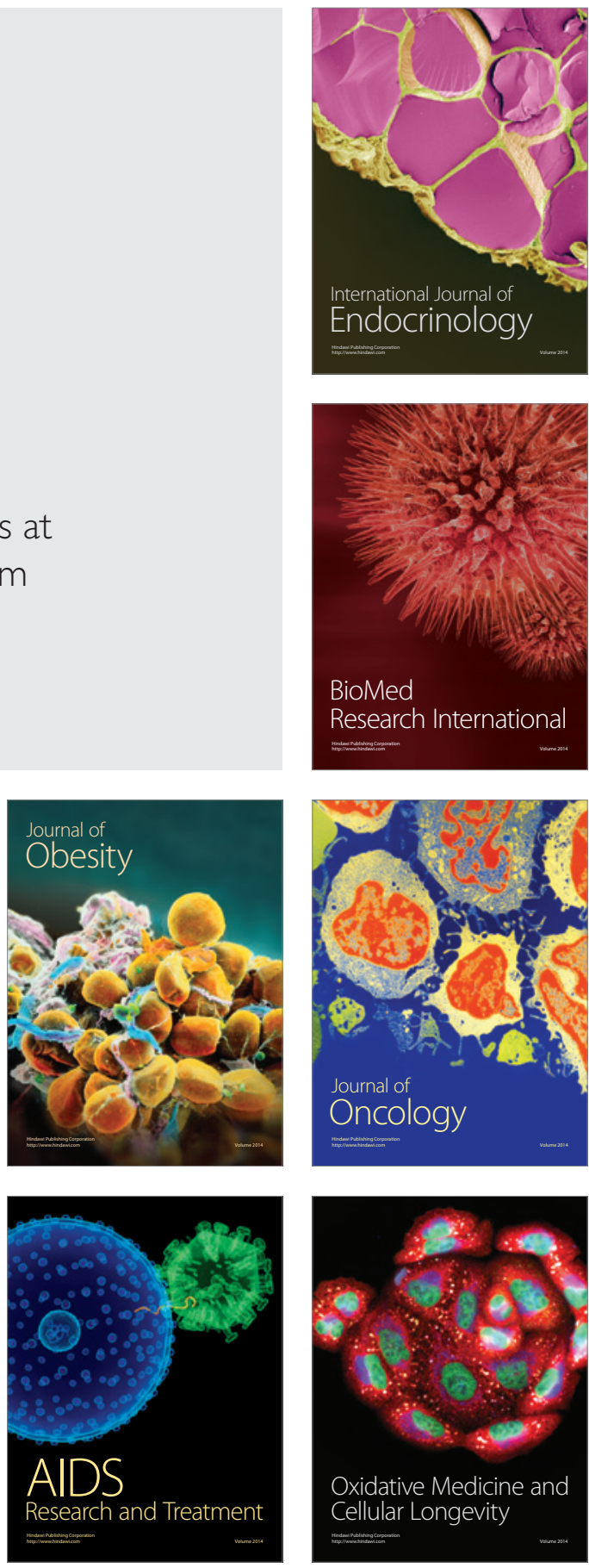